\title{
Gifts of Time: Watches and Clocks in Ottoman-British Diplomacy, 1693-1803
}

\begin{abstract}
Gift-giving was a crucial part of the regulation and practice of relations between European ambassadors and Ottoman state officials in Istanbul. Although largely dominated by textiles, timepieces played a crucial role in gift-giving practices on a number of levels. Taking the example of the British embassy in Istanbul in the eighteenth century and examining the detailed financial records of that institution, this article considers the significance of watches and clocks gifted by the British to different Ottoman officials on different occasions. By considering timepieces as social gifts to build individual relationships, as ceremonial gifts conforming to Ottoman expectations and practices, and as objects used to stimulate commercial interest, this article emphasises the importance of financial records and material objects as sources for reconstructing the practice of diplomacy, and demonstrates the shifting role of time pieces in British-Ottoman relations in the eighteenth century.
\end{abstract}

The study of diplomatic gifts in the Ottoman context is a small but growing part of the field, illustrating to historians of Ottoman-European interactions just how central gifts were to the performance of diplomatic relationships in Istanbul. ${ }^{1}$ In turn, these gifts and their associated practices reveal much about how the rhetoric of Ottoman-European diplomacy was reflected in practice, and provide useful evidence for changing consumption patterns in elite Ottoman society in Istanbul, and for the material links between diplomacy and commerce. Indeed, the materiality of these gifts - predominately textiles, but also a wide range of objects, from books to spectacles to the subject of this paper, watches - can perhaps get lost behind the exceptional beauty of imperial objects on display

1 Hedda Reindl-Kiel: East is East and West is West, and sometimes the twain did meet: Gift exchange in the Ottoman Empire, in: Colin Imber, Keiko Kiyotaki and Rhoads Murphey (eds.): Frontiers of Ottoman Studies, vol. 2. London 2005, 113-124; Cihan Yüksel Muslu: The Ottomans and the Mamluks: Imperial Diplomacy and Warfare in the Islamic World. London 2014, passim; Michael Talbot: British diplomacy in the Ottoman Empire during the long eighteenth century. $\mathrm{PhD}$ thesis London 2013, chap. 4; Harriet Rudolph: The material culture of diplomacy: The impact of objects on the dynamics of Habsburg-Ottoman negotiations at the Sublime Porte (1530-1650), in: Gunda Barth-Scalmani, Harriet Rudolph and Christian Steppan (eds.): Politische Kommunkation zwischen Imperien: Der diplomatische Aktionsraum Südost- und Osteuropa. Innsbruck 2013, 211-237; Fatma Açıkgöz: Fransızların 1681 Sakız Saldırısında Verdikleri Zarar Karşılığında XIV. Louis tarafından IV. Mehmet’e Gönderilen Tarziye Hediyeleri, in: Sosyal Bilimler 1, no. 1 (2011), 59-77. 
in museums and catalogues. The importance of thingness in considering historical objects has been the subject of significant discussion in recent years, a significant contribution to which was Bill Brown's 'Thing Theory' published in 2001. Brown argues for making the distinction between an object, which we use to look through to gain wider cultural or historical understandings, and a thing as an item's physicality, but stressing that only by 'turning away from the object/ thing dialectic' have historians and others been able to really get to grips with thingness. ${ }^{2}$ Strongly linked to thingness is the question of a thing's agency, developed in a number of respects from the work in sociology and anthropology of Arthur Gell and Bruno Latour - who famously declared that 'objects too have agency' - described in a more historicised sense by Ileana Baird as "its capacity to address, comfort, and help humans reassess the conflicting relationship with their past." ${ }^{3}$ Figuring out the links between objects, things, thingness, and agency requires a specific context and specific examples, and in this paper I will attempt to examine watches and clocks given as gifts from the British embassy to officials of the Ottoman court in the eighteenth century as objects of gift-giving, and things within a wider commercial setting. ${ }^{4}$ In his examination of gifts in French-Tunisian diplomacy in the eighteenth and nineteenth centuries, Christian Windler observed that the choice of gifts given by the French to the beys in Tunis were increasingly "objects suggestive of the capacity of Europeans to dominate nature by technological progress". ${ }^{5}$ Doubtless, this was part of the consideration in choosing timepieces as gifts in the eighteenth century. But by examining these watches from a variety of angles, they appear to play a far more complex role than simply as a mute object in a wider story of increasing European violence, domination, and technological nous, but contain their own stories that in turn illuminate other aspects of British-Ottoman interactions.

2 Bill Brown: Thing Theory, in: Critical Inquiry 28, no. 1 (2001), 1-22, here 3-4, 6.

3 Bruno Latour: Reassembling the Social: An Introduction to Actor-Network-Theory. Oxford 2005, 63-86; Arthur Gell: Art and Agency: An Anthropological Theory. Oxford 1998, 12-27; Ileana Baird: Introduction: Peregrine things: Rethinking the global in eighteenth-century studies, in: Ileana Baird and Christina Ionescu (eds.): Eighteenth-Century Thing Theory in a Global Context: From Consumerism to Celebrity Culture. Farnham 2013, 1-16, here 5-6.

4 On timepieces in the Ottoman context see: Avner Wishnitzer: Reading Clocks Alla Turca: Time and Society in the Late Ottoman Empire. Chicago 2015, especially chapters 1 and 2; Otto Kurz: European Clocks and Watches in the Near East. Leiden 1975; Netice Y1ldız: Osmanlı İmparatorluğu'nda İngiliz Saatleri ve Topkapı Sarayı Koleksiyonu, in: Belleten 70, no. 259 (2006), 919-962; Kemal Özdemir: Ottoman Clocks and Watches. Istanbul 1993; Gülay Durmaz: Zamana Yolculuk: Divan Şiirinde Saat ve Saat Çeşitleri, in: Turkish Studies 7, no. 2 (2012), 385-400.

5 Christian Windler: Tributes and presents in Franco-Tunisian diplomacy, in: Journal of Early Modern History 4, no. 2 (2000), 168-199, here 187. 
Theoretical categories about objects and things found elsewhere in the historiography are beginning to be considered in Ottoman studies, notably in Gülru Necipoğlu's beautiful consideration of floral patterns and the idea of ornament in the early modern Ottoman aesthetic, which needs to be quoted at length:

\begin{abstract}
Ornament not only negotiated intercultural boundaries but also defined the empire's territorial borders with a cohesive system of canonical motifs. This new aesthetic canon helped cement the hegemonic collective identity and esprit de corps of the multi-ethnic Ottoman ruling elite, making visible and more legible the augmented magnificence of an increasingly centralised empire extending of three continents. The language of flowers became the language of things, of empire. The functionality, materiality, and 'thingness' of objects with decorated surfaces which circulated and were exchanged as gifts, meant that their signification process was largely dependent on their context. Their interaction in specific settings, transactions, ceremonies, and spectacles with the gendered bodies of users and beholders activated diverse responses, informed by the subjectivity of individuals. ${ }^{6}$
\end{abstract}

The idea of ornament here is crucial. Ornament was, from the seventeenth century onwards, associated with the 'Orient' as a form of otherness. ${ }^{7}$ In part, this is due to ornament being somehow separate to the thing as more than mere embellishment, but was a function of understanding the "conceiving and perceiving" of an object and in particular as a definer of beauty. ${ }^{8}$ Ornamentation is not, therefore, the same as detail, which is, to use the term of Jasper Cepl, self-referential, in that, in the context of architectural theory, "the detail speaks only from the building, unlike the ornament: it starts there, where the architecture ceases, to speak for itself." ${ }^{9}$ These theoretical understandings have important implications for an analysis of timepieces given by the British to the Ottomans in the eighteenth century. As their aesthetic developed, they conformed more and more to the motifs described by Necipoğlu, enabling these British-made watches and clocks to speak the language of the Ottoman elite, and to participate in the ceremonies and transactions that formed Ottoman conventions of diplomatic (and other forms of) gift-giving.

How does this theory fit in with the raw material of the historical record? The primary basis of this study is the financial accounts of the British embassy in Istanbul, which, between the late sixteenth century and the turn of the nineteenth century, was financed by the Levant Company, a commercial monopoly that

6 Gülru Necipoğlu: Early modern floral: The agency of ornament in Ottoman and Safavid visual cultures, in: Gülru Necipoğlu and Alina Payne (eds.): Histories of Ornament: From Global to Local. Princeton 2016, 132-155, here 154.

7 Michelle Henning: Museums, Media and Cultural Theory. Maidenhead 2006, 123-124.

8 Clare Lapraik Guest: The Understanding of Ornament in the Italian Renaissance. Leiden 2016, 2.

9 Jasper Cepl: Ornament ist kein Detail, in: Dortmunder Architekturheft 24 (2012), 52-73, here 52. 
oversaw and regulated British trade to the Ottoman realms. This included financing the large number of gifts required to be given in a variety of social and ceremonial settings at the Ottoman court and beyond. Due to disruptions to trade in the middle of the eighteenth century that left the Company struggling financially, the British government began to take greater and greater responsibility for some aspects of embassy expenditure, including some areas of informal gift-giving, but the Company continued to pay for a significant part of gifts given. In the accounts, the entries look something like this:

His Excellency’s Audience with the Grand Vizier, 2 June 1766:

To the Reis Effendi, gold watch, repeating with chain, set with jewels; 550 p. ${ }^{10}$

On its own, this tells us a number of things about watches as gifts: that a particular Ottoman official received a watch in the summer of 1766 on the occasion of the ambassador's first audience with the grand vizier; that the watch was made from gold, was a repeating watch, set with unspecified jewels, and came with a chain; and that it cost 550 Ottoman gurus (around $£ 56$ at the time), a silver coin often called a piaster (hence the $p$ ). Within this short bit of administrative text, we begin to gain some insights into this watch as an object, as a thing, and as a commodity. On its own, however, it can only tell us so much. I hope to show that by considering hundreds of timepieces as a group over a century, narratives such as these show changes and continuities in watches as both objects and things, allowing us to explore the relationship between the materiality of timepieces and their functions in diplomacy practice and beyond.

\section{Timepieces as Social Gifts}

The Levant Company's accounts for the Istanbul embassy for the period between 1693 and 1803 provide varying degrees of comprehensiveness and detail in terms of narrative for each gift, but nonetheless give us a detailed sense of the gifts given to Ottoman officials that would be difficult, if not impossible, to reconstruct from anywhere else in either the British or Ottoman archives. The accounts have some gaps, particularly a rather unfortunate lack of records for the crucial midcentury (1745-64), and other gaps in the first half (1717-21, 1725-29), but nonetheless provide crucial insights into the practices of gift-giving from the British to a wide range of Ottoman officials. From the Levant Company accounts I have

10 The National Archives London (TNA), SP105/203, fol. 24. 
produced a database of over 10,000 gifts given between 1693 and 1803, among which can be found 457 watches and clocks, comprising 269 silver watches, 111 gold watches, 54 other or undefined watches, and 23 clocks. ${ }^{11}$ By examining the data over the eighteenth century, it is possible to discern trends in the gifting of watches that tell us much about changing patterns in Ottoman-British relations, particularly by looking at the kinds of Ottoman officials being gifted them, and the reasons for the gifting.

An analysis of the numbers involving watches shows a key split between the two halves of the century, both in terms of the officials who received gifts and the reasons for giving them. In the first half of the eighteenth century, watches were most commonly given as informal gifts (hibe) that were designed to cement and built friendships, and consequently to achieve particular diplomatic goals with the Ottoman state. According to the accounts ledgers, the most intense period of this sort of relationship building was between 1695 and 1716, a crucial period in British-Ottoman relations in three ways. First, this period was marked by British attempts to (successfully) secure mediation in the peace negotiations between the Ottomans and the Habsburgs, first at Carlowitz in 1699 and then at Passarowitz in 1718. Second, there was an ongoing commercial battle with the French for supremacy in the Ottoman market, where the British had been dominant for a number of decades, but which began to change in favour of the French following their successfully securing new Capitulations in $1673 .^{12}$ Thirdly, during the Nine Years' War (1688-1697) and the War of the Spanish Succession (1701-1714), the privateering wars between the British and the French in Ottoman waters caused significant tensions with the Ottoman government due to disruption caused to Ottoman trade and the violation of Ottoman ports. ${ }^{13}$

As a result of this period of commercial and political activity, gifts played a crucial role in gaining the favour and cooperation of Ottoman officials, and it is in this period that watches began to take on an important place in the British gift portfolio. Sometimes watches were ordered to be given to a certain official by the ambassador, and other times the officials themselves would request them as a gift, a long-standing practice that one can find in the letters of the Habsburg

11 Details of these gifts can be found in the embassy registers, at: TNA, SP105/177-181, 201-204, 206-207.

12 Edhem Eldem: French Trade in Istanbul in the Eighteenth Century. Leiden 1999, 13-15 and chapter 1 passim.

13 Michael Talbot: Ottoman seas and British privateers: Defining maritime territoriality in the eighteenth-century Levant, in: Pascal Firges et al. (eds.): Well-Connected Domains: Towards an Entangled Ottoman History, Leiden 2014, 54-70, here 59-64. 
ambassador de Busbecq in the sixteenth century. ${ }^{14}$ Until the 1720 s the most commonly recorded reason for gifting a timepiece was 'by order of His Excellency'. These watches went to relatively high officials or members of their retinue, including the grand vizier (or, in his absence, the kaymakam, his appointed deputy), senior officials of state, provincial officials, and military commanders, and secretarial officials. A significant number of these were given narratives such as "for his friendship", "for his assistance", "for his advice”, and "for his good services", indicated that these watches were given as tokens of appreciation for help provided by a variety of officials on different sorts of matters of state. Sometimes the narrative simply notes that services have been rendered, such as the reisülküttab (by the end of the seventeenth century akin to a foreign minister) in 1699, the scribe of the chief mektubcu (senior secretary) in 1709, the çavuşbaşı (chief of the imperial ushers) in 1710, and the sandik emini (treasurer) of the customhouse in 1715. ${ }^{15}$ Many of these cases were anonymised by the embassy clerks, so that "an effendi" was given a silver watch "for counsel and several good offices" in 1714, and "a person at the court" was given the same "for his good services on several occasions" in $1723 .{ }^{16}$ Generally, the more senior officials received the more expensive gold watches, while those lower down received silver pieces.

When a more detailed narrative is given, we can gain important insights into the details of daily diplomatic affairs that would not necessarily appear in any other documentation. For instance, a number of watches were given to officials who acted to free captive or enslaved British sailors, such as the kethüda (agent) of the kapudan paşa (grand admiral) in 1709, "a friend at the Porte” in 1710, and the head of the gatekeepers (kapıcılar kethüdası) of the çavuşbaşı, who helped to free nineteen sailors in $1713 .{ }^{17}$ Other officials received watches thanks to their facilitation of daily affairs, such as the reisülküttab who helped to secure berats (diplomas) for the embassy translators in 1703, and to the pasha of Belgrade in 1705 for ensuring the security of British merchants and travellers and enabling the safe passage of diplomatic and commercial correspondence. ${ }^{18}$ Disputes over customs rates seem to have been a key occasion of rewarding allies through gifts, such as two cases in 1723 seeing a gold watch given to the former defterdar (finance minister) Mustafa Pasha who provided help in Istanbul, and a silver watch to Mehmet

14 Ogier Ghiselin de Busbecq: The Life and Letters of Ogier Ghiselin de Busbecq, Seigneur de Bousbecque, Knight, Imperial Ambassador, ed. and trans. Charles Thornton Foster and F. H. Blackburne Daniell, vol. 2. Cambridge 2012, 84, 93, 112-115.

15 TNA SP105/177, fol. 7. TNA SP105/179, fol. 226; 282. TNA SP105/180, fol. 29.

16 TNA SP105/179, fol. 704. TNA SP105/181, fol. 171.

17 TNA SP105/179, fol. 226, 314, 545.

18 TNA, SP105/178, fol. 245, 357. 
Efendi, the former qadi of Aleppo, who assisted in a major dispute over customs rates in that city. ${ }^{19}$

As well as rewarding those who helped British interests, watches were used in the first decades of the eighteenth century to gain the favour of new allies. For this reason, the chief scribe in Belgrade received a gold watch in 1708 in the hope that he would help give assistance to British travellers and post travelling that way, the qadi of Aleppo received a silver watch in 1709, and the defterdar a gold watch in 1723 "to bespeak his favour". ${ }^{20}$ Indeed, favour was a crucial element of life at the Ottoman court, as at any royal hub, and gifts of watches were strategically made to curry favour with various favourites. Sometimes this involved playing the political game rather directly, such as a spring clock gifted to the kaymakam Hasan Pasha, a brother-in-law of the sultan and someone who the ambassador William Paget thought "stands fair for the [grand vizerial] seals"; this did not work out, as Amcazade Hüseyin Pasha retained his position, but nonetheless this incident shows the willingness of the British ambassador to use the gift of timepieces to seek favour at the highest level of the Ottoman court. ${ }^{21} \mathrm{~A}$ more common tactic was to target favourites lower down in the Ottoman hierarchy in the hope that they would speak well about the British and their interests at the higher levels, particularly favourites of the grand vizier such as an offical at the customhouse in Galata noted simply as an ăga (military and official honorific) gifted a gold watch in 1724, and the vizier's kapıcılar kethüdası given the same in 1735. ${ }^{22}$ Family members might also be targeted to gain official favour, doubtless the reason for the gifting of a bloodstone watch set with diamonds and rubies to the son of the new grand vizier, Şehla Ahmed Pasha, in $1740 .^{23}$

In addition to rewarding old allies and gaining new ones, watches were used on the order of the ambassador to placate officials who did not favour British interests, or to avert or rectify incidents that had the potential to damage British interests. A small number of such cases arise in the accounts in the late 1700s: a gold watch to the pasha of Belgrade in 1707 to "prevent his being troublesome" by hindering the passage of British post; and a silver watch in 1708 to the tersane kethüdası (steward of the shipyards), simply described as "a troublesome man". ${ }^{24}$ Two rather more exceptional cases occurred in the 1730s, in which watches were

19 TNA, SP105/179, fol. 545-546. TNA, SP105/181, fol. 149, 171.

20 TNA, SP105/179, fol. 226. TNA, SP105/181, fol. 148.

21 TNA, SP105/201, fol.7. For a discussion of court politics in this period, see: Michael Nizri: Ottoman High Politics and the Ulema Household. Basingstoke 2014, 87-137.

22 TNA, SP105/181, fol. 230. TNA, SP105/202, fol. 7.

23 TNA, SP105/202, fol. 7.

24 TNA, SP105/179, fol. 48, 50, 119, 228. 
used, alongside other gifts such as money and textiles, to gain a desired outcome. The first example took place in 1732, when a feast on board the British merchant ship The Williams broke with established convention and fired celebratory cannon during the holy month of Ramadan, resulting in the grand vizier, Topal Osman Pasha, censuring the ambassador, the Earl of Kinnoull, and arresting two British merchants in protest. ${ }^{25}$ In order to gain support at the Ottoman court against Topal Osman's actions, Kinnoull spent a significant amount of money - 2,260 Ottoman guruş - gifting watches to senior members of the Ottoman court, with a repeating gold watch set with diamonds and a gold chain given to the yeniçeri ağası (commander of the janissaries) İsmail Pasha, another repeating gold watch set with diamonds to the defter emini (senior record keeper), a plain gold watch to his baş çuhadar (chief valet), as well as a lavish table clock with silver pillars to the reisülküttab, and a gold watch to his kethüda. ${ }^{26}$ After these gifts, and some strenuous negotiation resulting in a promise not to let such an incident occur again, Topal Osman's anger abated and the British merchants were freed. The second preventative example came from two years earlier when, in 1730, the Ottoman government planned to send an ambassador to London carrying the formal letters of the new Sultan Mahmud I (r.1730-1748). Wary of the expense this would entail for both the British government and the Levant Company in terms of extra gifts and entertainments, Kinnoull opposed this proposition "by all proper solicitations at the Porte". ${ }^{27}$ What he did not mention in his formal correspondence was that he had spent 1,380 Ottoman guruş on watches gifted to Ottoman officials, with gold repeating watches given to the kethüda and mektubcu of the grand vizier Silhadar Damad Mehmed Pasha, two engraved ("chased") gold watches to the reisülküttab and his steward, as well as a silver watch to an unnamed efendi. ${ }^{28}$

By the time Kinnoull gifted these expensive timepieces in the early 1730s, the dynamic in terms of gift-giving had already changed. The giving of timepieces by the British ambassadors seems to have stimulated an interest in these items among Ottoman officials, and consequently, from the 1710s, the embassy accounts show that an increasing numbers of watches were specifically requested by a variety of individuals, amounting to sixty-five pieces between 1704 and 1741 . Of course, this is not to say that this was a new practice, but rather that the numbers seemed to be growing in terms of Levant Company gifts; on the other hand, it could indicate a shift in the Ottoman market from French to British watches. Sometimes these

25 TNA, SP97/26, Earl of Kinnoull to the Duke of Newcastle, 25 January 1731/2.

26 TNA, SP105/202, fol.7.

27 TNA, SP97/26, Kinnoull to Newcastle, 3 January 1731 OS.

28 TNA, SP105/202, fol. 5. 
gifts were noted as being requested in return for favours done or services rendered, as with a double gold engraved watch requested by the çavuşbaşı in 1705 , and a "fine" clock asked for by the kapudan paşa in $1716 .{ }^{29}$ Others were given to rather more difficult officials, such as a striking gold watch given to the kethüda of the grand vizier in 1722, with the narrative noting, "he having demanded the same, and it not being prudent to refuse him, considering the vizier is absolutely governed by him." ${ }^{30}$ The gümrük emini (chief customs official, often referred to as "the customer") requested a gold watch in 1723, as he was "not [...] content with the presents already given him", which seems to have been another gold watch and some textiles ${ }^{31}$ Many of these particular entries are lacking narrative other than the fact that the officials requested the item, but examining the breakdown of the recipients of those gifts indicates a success on the part of the British in generating interest in British watches as gifts among the upper echelons of the Ottoman administration.

Watches given on the ambassador's orders were the main form of gifting for timepieces in the first half of the eighteenth century, with sixty-nine watches and clocks given to Ottoman officials on that account between 1693 and 1722, with a further sixty-six given between 1723 and 1742. As for timepieces requested by Ottoman officials, thirty-one were requested between 1693 and 1722, and thirty-five between 1723 and 1742. In numerical terms there seems to be little difference, but the big change was in the position of the officials being given or requesting watches. In the period up to 1722, the majority of recipients were provincial officials (the pashas of Belgrade and Aleppo and their officials in the main) along with friends working for British interest at the Ottoman court, and assorted palace and secretarial officials. In other words, watches were given to ensure favour with certain key provincial officials, especially in terms of protecting freedom of movement in the transit city of Belgrade and freedom of trade in the commercial centre of Aleppo, and to ensure the success of British petitions at the Ottoman court by using the influence of anonymous friends and gaining the favour of pivotal scribal and palace figures. This changed, however, from the 1720s with the majority of watches going to the grand vizier and members of his retinue, from his kethüda to his relations, particularly in the periods in office of Damad İbrahim Pasha (1718-30) and Hekimoğlu Ali Pasha (1732-35).

We can look at this data in two ways. First, the role of watches, which had been given largely on an ad hoc basis to gain favour in the provinces and, through

29 TNA, SP105/178, fol. 356. TNA, SP105/180, fol. 55.

30 TNA, SP105/181, fol. 65.

31 TNA, SP105/181, fol. 147. 
unnamed helpers and a variety of high, middle, and lower ranking secretarial and palace officials, at the Ottoman court, began to be concentrated on the grand vizier and his retinue and the senior officials of state. This, perhaps, is evidence of a shift in the workings of the Ottoman court, away from a reliance on favourites and gatekeepers to a more centralised state system vis-à-vis diplomats. This shows a change in the use of watches in diplomacy, and therefore that the watch changed somewhat as an object in these first decades of the eighteenth century. But what about watches as things? Aside from some few exceptional examples, these watches were largely the same throughout in terms of the description in the accounts, whether they were engraved or plain, gold or silver, with chains or without, chiming or silent; no detail is given on whether the watches were painted or not, although the material evidence suggests that painted watches became more popular as the century wore on. Thus, in observing that the watch as an object undergoes a subtle change in use in this period, it is easy to overlook the fact that they remained the same things as objects, but their materiality changed, with gold watches making way for those made of silver. However, their thingness is highlighted only when encountering narratives of broken clocks and watches, when they cease to function in whatever role they play as objects of prestige and enjoyment, transforming briefly into cases, cogs, and wheels. ${ }^{32}$ This stresses the relationship between the watches' objectness and thingness: they receive meaning as objects only by their functioning, and in ceasing to function the maintenance of their thingness becomes central to the maintenance of the wider relationship between the British embassy and the Ottoman court.

\section{Timepieces as Ceremonial Gifts}

If the earlier part of the eighteenth century was marked by the giving of watches as social gifts by the British embassy, then the second half of that century saw a distinct move towards more a more formalised and standardised place for watches within gift-giving practices. The two manifestations of this are the inclusion of watches and clocks in the formal set of gifts given to the sultan and grand vizier and a number of their retinue on the first audience of a new ambassador, and the use of watches in the tributary gifts, which I refer to as pişkeş gifts after the Ottoman term that was used in official documents, and in the Imperial Capitulations, to refer to the compulsory gifts given regularly on certain major occasions such as audiences

32 Brown, Thing Theory, 4. 
with major officials, and on officials' appointments to new posts. Certainly one finds exceptional timepieces given on such occasions in earlier periods - such as the famous clock of Thomas Dallam - but by the eighteenth century there were fixed gifts given on these occasions, with watches and clocks only playing a regular part in the embassy's gifts from middle of the century. ${ }^{33}$ One of these occasions of tributary gifts was the annual gifting to Ottoman customs officials to ensure the continuation of favourable customs duties and secure the cooperation of those officials in commercial disputes, discussed in more detail below. Indeed, well over half of the watches and clocks gifted to Ottoman officials in the eighteenth century by the British embassy did not go to the high ministers of state, but to the officials who oversaw the customhouses in Istanbul. This shift is graphically represented in Figure 1, with the first half of the century showing a gradual increase in the value of watches given, hitting a peak in the 1730s and then, following the unfortunate gap in records in the middle of the century, taking more of a cardiac cycle form, with the shape of the value of watches given formed by an annual constant provided by watches gifted to the customhouse, and punctuated by the significant increase in expenditure on a new ambassador's arrival.

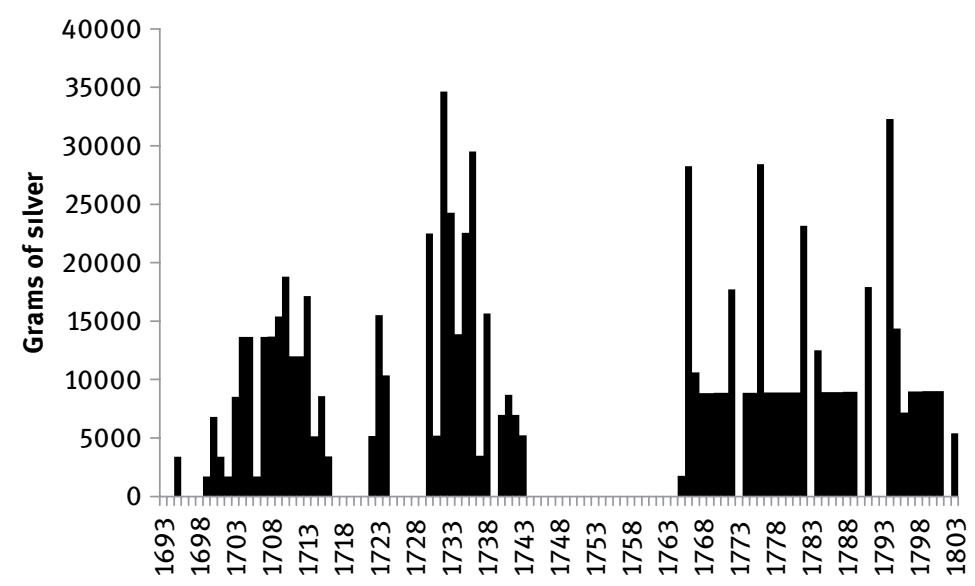

Figure 1: Value of watches and clocks gifted to Ottoman officials from the British embassy accounts, $1693-1803 .^{34}$

33 Lawrence Danson: The sultan's organ: Presents and self-presentation in Thomas Dallam's Diary, in: Renaissance Studies 23, no. 5 (2009), 639-658.

34 TNA, SP105/177-181, 201-204, 206-207. Values in Ottoman guruş have been converted to grams of silver to adjust for inflation, using Şevket Pamuk: A Monetary History of the Ottoman Empire. Cambridge 2000, 163. 
The gifting of watches and clocks had not been a part of the gifts of a new ambassador on a regular basis throughout the seventeenth and eighteenth centuries, although the famous timepiece commonly known as Dallam's Organ, a musical clock gifted by Elizabeth I in 1600, is perhaps the most well-cited example of a British diplomatic gift at the Ottoman court. ${ }^{35}$ Rather, the vast majority of gifts on the new ambassador's arrival were textiles, specifically cloth and silk kaftans. In 1736, on the arrival of Sir Everard Fawkener, two silver watches were gifted to the kaymakam's mektubcu and to the teşrifatçı (master of ceremonies), so it is possible that the practice of giving watches for initial audiences began at this point, although it is difficult to tell because of the missing records for the period $1745-1764 .{ }^{36}$ The significance of this shift is perhaps a comment on a shifting balance of power reflected in diplomatic ceremonial. The giving of kaftans - a practice that largely continued, although on a far smaller scale - was a longstanding Ottoman practice, one to which all ambassadors had been obliged to conform. The introduction of timepieces marks a distinctly European product performing a central role in a key ceremonial event in a way that had not happened previously on a standardised basis.

These were not the first watches or clocks formally gifted to an Ottoman sultan or his court by the British embassy. Three watches gifted to Sultan Ahmed III (r.1703-1730), described as "striking the hours and quarters", appear in the embassy accounts in 1712, and doubtless a number of the other timepieces given to other Ottoman officials ended up in their monarch's collection. ${ }^{37}$ From the description of the clocks given as part of the formal ceremonial on the arrival of John Murray in 1766, Sir Robert Ainslie in 1776, Robert Liston in 1793, and the Earl of Elgin in 1803, some impressive timepieces were given. ${ }^{38}$ At the audience with the sultan, the sultan himself received an expensive "table clock", the one in 1794 "with a stand", and that in 1803 "musical", and the grand viziers received similar items at their audiences, all noted as "musical table clocks" in the embassy accounts. Although it is difficult to pin-point exactly which specific clocks these might have been - there are a number in the Topkapı Palace collection that would fit the bill - we can get a sense of the aesthetic of these table clocks from the example from the Victoria and Albert Museum's collection below (Figure 2). ${ }^{39}$ This piece, made from painted wood adorned with cut glass and brass mounts by

35 Ylldı, İngiliz Saatleri, 927-928.

36 TNA, SP105/202, fol. 5, 11.

37 TNA, SP105/179, fol. 507.

38 TNA, SP105/203, fol. 24; 143-144. TNA, SP105/204, fol. 6, 8-9, 12.

39 For an example from Istanbul, see: Topkapı Sarayı Müzesi, Saatler Bölümü, 53/27. For a catalogue of this permanent exhibition, see: Feza Çakmut: Topkapı Palace Clock Collection: Exceptional Timepieces at the Seraglio. İstanbul 2013. 
George Prior, is a very good example of the sorts of clocks exported to the Ottoman realms in the later eighteenth century, and, given that Prior was the most notable watchmaker for the Ottoman market in this period, it is evidence of a clear link between commercial interest and gift-giving practices.

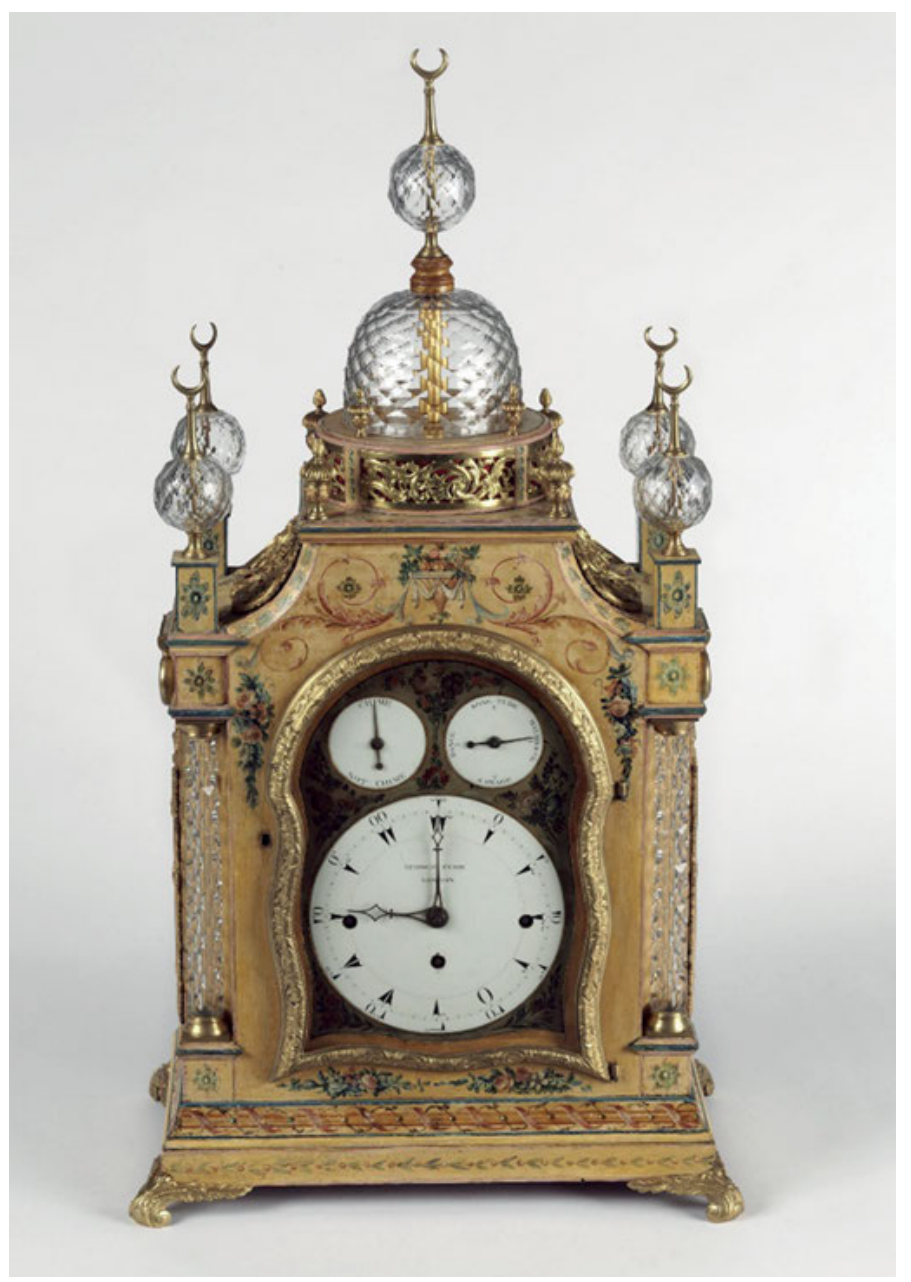

Figure 2: A George Prior musical table clock, c. 1790, Victoria \& Albert Museum, London, W:1:1, 2-1971, (C) Victoria \& Albert Museum.

This clock is a good match for the sort of 'musical clock' noted as given in 1803. As well as having a "chime" and "not chime" setting, this particular clock has four songs available: "Malbrouck", perhaps the French song Malbrouck s'en 
va-t-en guerre; "Samahe", either a corruption of semah, a form of dance associated with sufis, or of semai, the final movement in a piece of Ottoman classical music; an unspecified "dance"; and another unspecified "song Turk", which could be a version of an Ottoman song, or an imagined tune. ${ }^{40}$ As with the music choices, the design of the clock is a mixture of Ottoman and European taste, although the overall effect is clearly intended to evoke Ottoman architecture with minaret-like structures and a dome, all topped with crescents. It is through an object like this that we can also pause to consider its thingness. As well as the more obvious attempts to be Ottoman, the key is really in the painted wood. This is the floral style, that Ottoman aesthetic currency, that Necipoğlu demonstrated was so central to Ottoman thingness in this period as a "recognisable visual idiom". ${ }^{41}$ Beyond the striking design and musical delight, the pastel background covered with bunches and bouquets of vivid flowers (Figure 3), showing that the fantastical structure of the clock is firmly rooted in the Ottoman floral aesthetic, providing well-considered ornamentation that adds to its currency as an object.

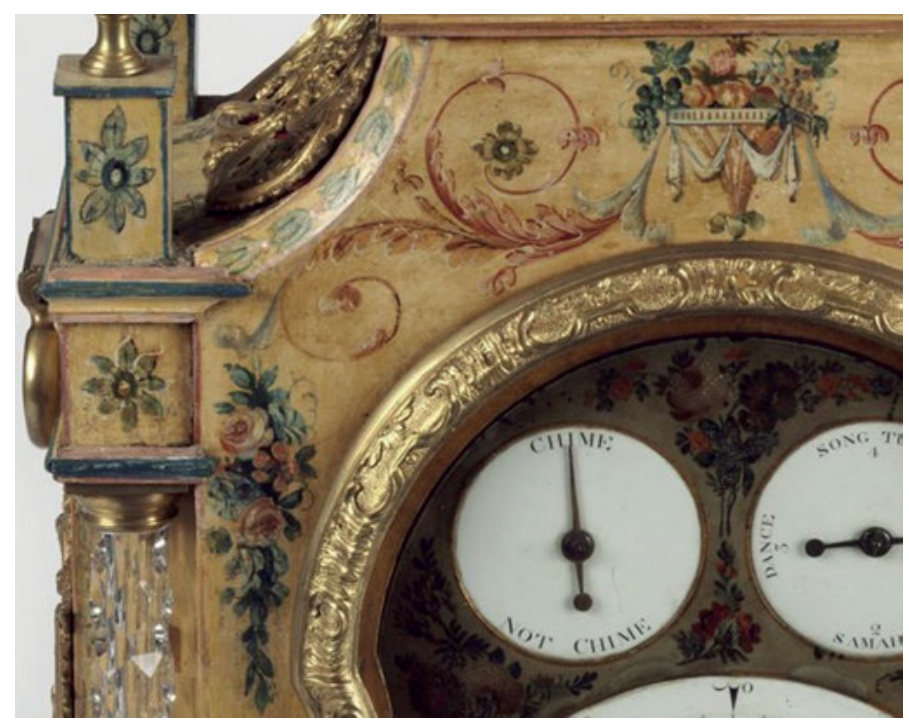

Figure 3: Detail of floral painting on George Prior musical table clock, c. 1790, Victoria \& Albert Museum, London, W:1:1, 2-1971, ( ) Victoria \& Albert Museum.

40 For more on the sorts of songs found on British clocks, see: Ylldız, İngiliz Saatleri, 937-38. 41 Necipoğlu, Early modern floral, 154. 
Such elaborate pieces were, however, exceptional. The difference in cost between the clocks for the sultan and the grand vizier are telling, with 280 gurus for the grand vizier's clocks and 1,150 guruş for those given to the sultan. This was not the most expensive gift given - for instance, in 1794 Selim III received a brocade kaftan worth 1,200 guruş - but was not something to be given on a regular basis. Rather, as with other forms of gift-giving, watches were the most common kind, with gold watches given to the grand vizier and reisülküttab for the first audience with the grand vizier, some of which were very expensive indeed, and a much cheaper silver watch given to the head teşrifatçı at the first audience with the sultan. These timepieces, accompanying the more traditional textile gifts, were on the whole top-end items for the consumption of the most senior figures in the Ottoman government, and a mark not only of British respect through their value and aesthetic, but also a mark of increasing British dominance in foreign commerce in the Ottoman relams, in which timepeices played a small but growing role.

These clocks and watches were high-quality pieces given on an official occasion of state. As noted above, however, the majority of watches given in this later period were to the officials of the Istanbul customhouses, perhaps lower down on the scale of official rank, but of vital importance to the primary purpose of British relations with the Ottomans, trade. The use of watches in cementing relations with these key officials, as with much of what we have seen was an evolutionary process beginning at the end of the seventeenth century. By 1699, the gümrük emini (chief customs official) received a cloth kaftan, sometimes paired with a satin kaftan, on his appointment to the position. ${ }^{42}$ Aside from a gold watch in a double gold case given in 1704, this was the standard model of pişkeş to the customhouse until the 1720 s. $^{43}$ From 1723 , however, a new model begins to emerge that saw the narrative in the accounts explain a number of gifts to set officials of the customhouse "for renewing the tariffs", that is, to ensure the implementation of the extra-capitulatory customs duties applicable on goods imported to and exported from the Ottoman Empire by British merchants. These officials were: the gümrük emini; his mühürdar (seal-keeper); the yazıcı (scribe) of the customhouse; the nazir (overseer) of the customhouse; and an official referred to initially as the "Jew waiter" and more commonly as the "Jew stimador", the appraiser of goods in the customhouse, whose Ottoman title was arayıcı, and who, as a Jew, apparently also went by the Ladino title of estimador. The primary recipient in terms of

42 TNA, SP105/201, fol. 4.

43 TNA, SP105/178, fol. 332. 
value was the gümrük emini, who received between seventy and ninety percent of the value of gifts given for this annual pişkeş, the item breakdown of which can be seen in Figure 4 below.

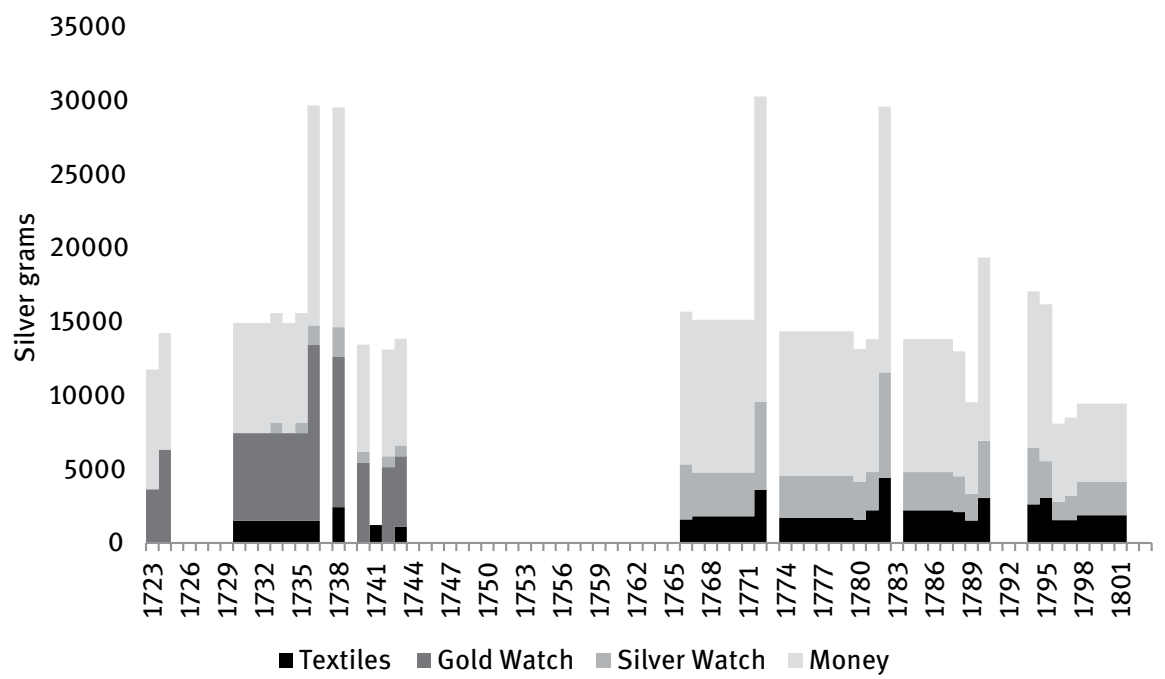

Figure 4: Value gifts given to the officials of the Istanbul customhouse by the British embassy, $1723-1803 .{ }^{44}$

To begin with, only the gümrük emini received gifts on this occasion, specifically a gold watch and the sum of 500 guruş in cash. This puts the watch into a rather different setting than it had been in as a social gift or as a ceremonial gift, serving far more as a commodity than an object to be enjoyed; it was part of a payment, valuable because of its material value as a commodity rather than its wider functionality. From 1730, gifts for renewing the tariffs were extended to include the four other key customs officials noted above, with the mühürdar receiving one or two silver watches annually. The arayıc sometimes received a silver watch and sometimes lengths of cloth, whilst the yazıcl and the nazir received only textiles. This continued until the early 1740 s when the records stop, but when

44 TNA, SP105/177-181, 201-204, 206-207. Values in Ottoman guruş have been converted to grams of silver to adjust for inflation, using Pamuk, Monetary History, 163. N. B.: Some years saw two sets of gifts given at the beginning and end, leaving no gifts for the following year (e.g. 1736, 1738, 1772, 1782). 
they resume in the 1760 s the picture is rather different. Now, the gümrük emini no longer received a gold watch, but cash in lieu, together with a cloth kaftan. The mühürdar continued to receive his silver watches, together with the yazıcl and nazir, who received a silver watch together with fabric lengths. The watches had been transformed into a form of salary supplement, in the gümrük emini's case in the later period converted into hard cash, but for the others remaining a solid form of silver capital, a guaranteed income from the British almost every year to grease the wheels of trade, promoting commerce and advertising British industry. This is the thingness of the watches almost as a raw commodity, and presents us with a link between the watch as an object and as an item of value, not least in commercial terms.

\section{Aesthetics and Commerce}

As has been seen, hundreds of watches and clocks were gifted to Ottoman officials. Although the permanent collection of clocks at the Topkapi Palace museum in Istanbul contains many wonderful examples of the expensive clocks given to the sultans, these are primarily later items, often produced by George Prior. The example in Figure 3 above was carefully crafted to appeal to an elite Ottoman aesthetic, no doubt through some trial and error. However, as most of the clocks and watches gifted did not go to the sultans, but to his officials of various ranks, the collections in British museums and auction houses give us a better insight into the aesthetics of the sorts of timepieces used as regular gifts by the embassy, particularly the gold and silver watches. The accounts of the Levant Company leave some clues as to the composition of the clocks and watches presented, as well as details of their cases.

Most of the adjectives used to describe these various timepieces were mechanical - "repeating”, "striking” - or qualitative - "handsome”, "fine”, "neat" leaving much to the imagination in terms of design. A number of watches from the early eighteenth century are described as having "studded" cases, although it is not specified what they were studded with. A number came with chains, but very often these were gifted separately. With the majority of the watches were made of either silver or gold, other materials very rarely featured, such as an agate watch set in gold given to the kethüda of the grand vizier in 1732, and a shagreen watch studded with silver requested by the çavuşbaşı in 1733 together with a similar

45 TNA, SP105/202, fol. 4, 6. 
piece given to the baş çuhadar (head valet) of the reisülküttab in $1734 .{ }^{45}$ These few items aside, varying qualities of gold and silver were the materials from which most of the watches were fashioned. In the first part of the eighteenth century, the number of gold and silver watches given were almost equal, whereas by the later part of the century, with informal hibe giving largely off the embassy's accounts and the new importance of watches at arrival ceremonials and for pişkeş at the customhouse, gold watches were used only for the former (Figure 5).

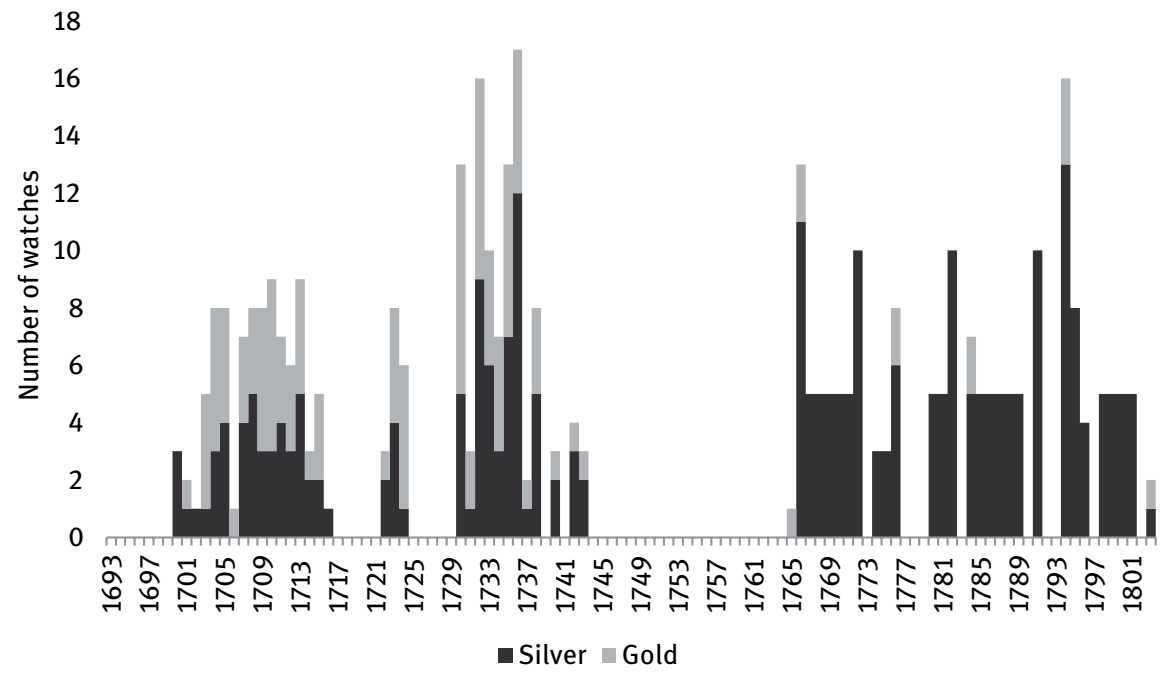

Figure 5: Number of silver and gold watches gifted to Ottoman officials by the British embassy, $1693-1803 .^{46}$

A significant number of these watches in the 1730s were described as "chased", meaning engraved, such as a chased gold watch "of the best sort" given to the baş tercüman (head translator) of the Ottoman court given when he delivered news from the grand vizier of an Ottoman victory under Topal Osman Pasha against an Iranian force at Baghdad in $1733 .{ }^{47}$ However, a degree of uniformity began to appear from the 1730s, with the arrival on the scene of London watchmakers Markwick and Markham, whose watches became the embassy's timepieces of choice.

46 TNA, SP105/177-181, 201-204, 206-207.

47 TNA, SP105/202, fol. 4. 
The first recorded use of a Markwick watch as a gift in the Levant Company accounts was on the request for a watch by the mühürdar (seal-keeper) of the grand vizier in 1732, described in the ledgers as "one of the best silver watches of Markwick's making, with [a] very fine new-fashioned chain”. ${ }^{48}$ Only two others are recorded being given in the 1730s, both silver, to the kethüda of the kapudan paşa in 1733 and the yeniçeri ăgası in 1738. However, from 1740, Markwick watches became a staple of gift-giving, being the sole make of watches gifted to the customs officials for their annual pişkeş gifts. The reason for Markwick's success is in the watches' design. Attempts to make watches suitable for the Ottoman market can be found in the seventeenth century, many of which had gilt cases and dials that featured Arabic numerals (that is, ', r, r, as opposed to I, II, III or 1, 2, 3). ${ }^{49} \mathrm{By}$ the time that Marwick's watches became the embassy favourite in the middle of the eighteenth century, this was the standard design. This was surely part of the appeal of these items, and of Markwick's timepieces in particular, in that careful thought went into how to make these items attractive to the Ottoman market. Some of these had intricate dials, with a particular form of decoration known as champlevé picking out the detail on the numerals. ${ }^{50}$ More common, however, is the style of a Markwick Markham clockwatch of about 1750-1775 (Figure 6).

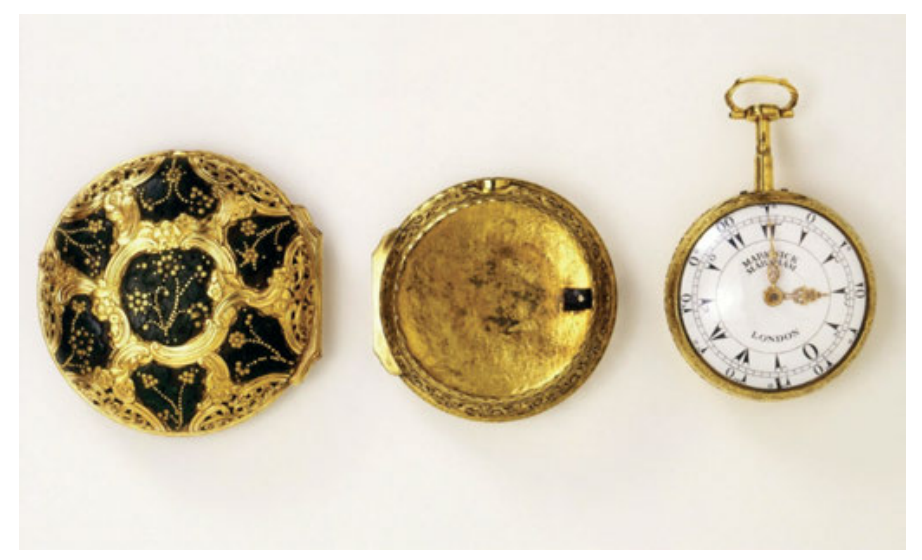

Figure 6: A Markwick Markham clockwatch, c.1750-1775, Victoria \& Albert Museum, London, 365 to B-1897, (C) Victoria \& Albert Museum.

48 TNA, SP105/202, fol. 6.

49 For instance: British Museum, Britain, Europe and Prehistory Department, 1958.1201.2239.

50 See for instance Markwick Markham no. 2339, a silver and tortoiseshell watch made for the Ottoman market c. 1765. Christie's, sale 2326, 2010. The Metropolitan Museum of Art, 17.190, 1632, a gilt metal and enamel watch, c. 1740-60. 
Markwick watches, as well as those made by Daniel de St. Leu and George Prior, tended to have a relatively simple face with clear Arabic numerals. The clockwatch above gives a good idea of the sorts of design found on watches in general, and the leather and gilt case on this one provides an indication of some of the studding found on watches. A large number of watches in museum and auction house collections, particularly from the later eighteenth century, both of Markwick Markham and George Prior, are decorated with landscape scenes, with pastoral scenes favoured in the middle of the century, the motif of a ship sailing under a castle by an arched bridge more common going into the nineteenth century, and floral designs throughout, again playing to an accepted Ottoman aesthetic in order to better market the watches and to ensure that they could seamlessly be taken into Ottoman elite culture. ${ }^{51}$ One English source noted in 1712 that "Turks [...] will buy no watches or clocks which have any figures of live creatures about them", and so it seems that the British watchmakers learned quickly to avoid such images. ${ }^{52}$

If these watches were designed so that they would appeal to the Ottoman market, the question then arises as to whether or not these items were actually used or not. Evidence for a potential answer can again be found in the embassy accounts ledgers, which detail all of the expenditure of the embassy, including a category of 'petty expenses', which covered a variety of outlays required in the daily functioning of the embassy. Among these, from the mid-1700s, there begins to appear outlays for the maintenance and repair of watches gifted to Ottoman officials. Initially this appears to have happened on an ad hoc basis, with officials sending to the embassy for repairs as and when needed. For instance, one of the earlier examples, from 1707, provides a cost of 51/2 guruş for "mending a watch for Sig[no]r Maurocortado", that is, for Alexander Mavrocordatos, who was the head translator at the Ottoman Porte and a central figure in Ottoman-European diplomacy at the turn of the eighteenth century. ${ }^{53}$ From this point onwards, almost every month contained details of expenditure for fixing Ottoman watches, from minor repairs such as the "mending of a watch of the chousbassi [çavuşbaşl]" costing 41/4 guruş in 1708, to "mending a repeating watch of the pasha of Belgrade with sundry new wheels" that same year for $202 / 3$ guruş. ${ }^{54}$ This demonstrates that

51 For example: Christie's, sale 2496, 2011, a gold Markwick watch no. 16835, c. 1750. Museum of London, C1478, a gold and enamel Markwick watch, c. 1780. Christie’s, sale 2610, 2012, a gold George Prior watch no. 40767, c. 1813. The Metropolitan Museum of Art, 47.33.2a-d, a gold and diamond Markwick watch, c. 1798.

52 Atlas Geographicus: Or, a Compleat System of Geography, Ancient and Modern. London 1712, 285.

53 TNA, SP105/179, fol. 45.

54 TNA, SP105/179, fol. 116, 117. 
this particular form of gift had a definite afterlife, that the act of giving did not resign responsibility for its maintenance and repair. This is perhaps reflective of the importance of the expertise of British watchmakers in Istanbul at this time, but also shows that these watches were being used, monitored, and maintained by their new Ottoman owners. Therefore, when Sir Robert Sutton ordered the gifting of a gold watch to the pasha of Belgrade in 1707, costing 110 guruş, he would have been aware - or at least become aware - that this gift would hold a longer-lasting connection in terms of both expense and responsibility.

The increasing demand for the maintenance of watches and clocks saw a new tactic being developed by the embassy accountants in the 1710s. In part this seems to have been in response to a number of serial watch-breakers, notably the qadi of Galata, who sent watches in for repair three times in 1708 alone. ${ }^{55}$ One narrative from 1723 noting the repair for the large sum of $261 / 2$ gurus of a watch belonging to the reisülküttab as being necessary due to "it being much abused". ${ }^{56}$ Occasional references can be found as well in the ambassadorial correspondence, when one of Sultan Ahmed III's favourites asked the ambassador Edward Wortley to fix a number of the sultan's watches, brought to the ambassador personally by the governor of the district of Galata. ${ }^{57}$ As a result, from 1709 onwards, the embassy would pay quarterly bills to a number of British watchmakers in Istanbul who had fixed the watches and clocks of Ottoman officials, with a typical narrative saying that the outlay was for "mending watches for several great Turks for these three months past". The names of some of these watchmakers are given, with a Mr Terrier and a Mr Bird being the two most common in the 1710s and 1720s. By the height of the giving of watches as social gifts in the 1730s, these quarterly payments for mending the watches of Ottoman officials averaged around 32 guruş with the narrative emphasising that these repairs were for "the grand signior [sultan] and his great officers". ${ }^{58}$

This level of expenditure for quarterly repairs continued into the 1740s, and although this did not amount to much in terms of the overall embassy expenditure, the significance of maintaining watches is crucial. Ottoman estate inventories do list watches, particularly the silver watches that were common in British diplomatic gift-giving, showing that they were important as moveable capital. ${ }^{59}$

55 TNA, SP105/179, fol. 57, 117, 222.

56 TNA, SP105/181, fol. 46.

57 TNA, SP97/24(1), Edward Wortley to James Addison, 2 August 1717 OS.

58 TNA SP105/202, folks. 2 (Feb. 1731), 4 (May 1731), 2 (Aug. 1731), 4 (Nov 1731), 2 (Feb. 1732), 4 (May 1732), 2 (Aug. 1732), 3 (Nov. 1732), 2 (Apr. 1733).

59 M. Şükrü Hanioğlu: A Brief History of the Late Ottoman Empire. Princeton 2008, 29-33. 
Indeed, Avner Wishnitzer has convincingly shown that throughout the eighteenth century, clocks and watches became a more conspicuous part of elite Ottoman society, but did not displace the existing time-systems largely administered through religious establishments, even as the system posed by European timepieces became more and more prevalent in official circles. ${ }^{60}$ Marlene Kurz has posited that watches were adopted on "religiously neutral grounds", meaning that they posed no threat to the established muvakkithanes, the timekeeping facilities attached to mosques. ${ }^{61}$ There was clearly a place for these watches being used, but it was only with the beginning of the nineteenth century that clock times began to supplant prayer times as the measure of time. ${ }^{62}$

British watches gifted to Ottoman officials could serve a useful function, and were certainly used by the officials who received them. It is difficult to trace how watches were used in practice, but the amount of repair work carried out indicates enough attention was being paid to them that they were not simply ornamental. ${ }^{63}$ The question of functionality is crucial, as it helps to explain why watches in particular were chosen as gifts. Not only does the breaking of the watches refocus our attention on them as things, but it also allows us to picture these now static items as working, functioning, and interactive objects. More than this, it reminds us that these watches were not just part of a wider gift story, but part of a broader commercial narrative. The growing use of watches as gifts in diplomacy has a clear link to the growing success of British watches in the Ottoman market. By examining the British customs statistics for the eighteenth century, a significant increase in demand can be observed from the late 1710s, at the same time that watches were being established as regular diplomatic gifts at the Ottoman court. The trend of growth was only hampered by the general failure to British commerce in the Levant during major conflicts with the French (Figure 4), during the War of the Austrian Succession (1740-8), the Seven Years' War (1756-63), and the War of American Independence (1775-83). By the beginning of the 1720s, the average annual value of timepieces imported had increased to $£ 990$ compared with $£ 140$ two decades before. The economic

60 Wishnitzer, Reading Clocks, 32-44.

61 Marlene Kurz: Modernisation in the Ottoman Empire between the Treaty of Karlowitz (1699) and the Reign of Mahmud II (1808-1839): A Process of Cultural Transfer, in: Plamen Mitev et al. (eds.): Empires and Peninsulas: Southeastern Europe between Karlowitz and the Peace of Adrianople, 1699-1826. Berlin 2010, 163-170, here 169.

62 Wishnitzer, Reading Clocks, 11.

63 Fatma Müge Göçek: East Encounters West: France and the Ottoman Empire in the Eighteenth Century. Oxford 1987, 104-106. 
turmoil caused by numerous conflicts in the middle of the century saw this commodity, as with others, decline, but by the end of the 1760s the market exploded, entering the nineteenth century with annual average imports of $£ 3,000$.

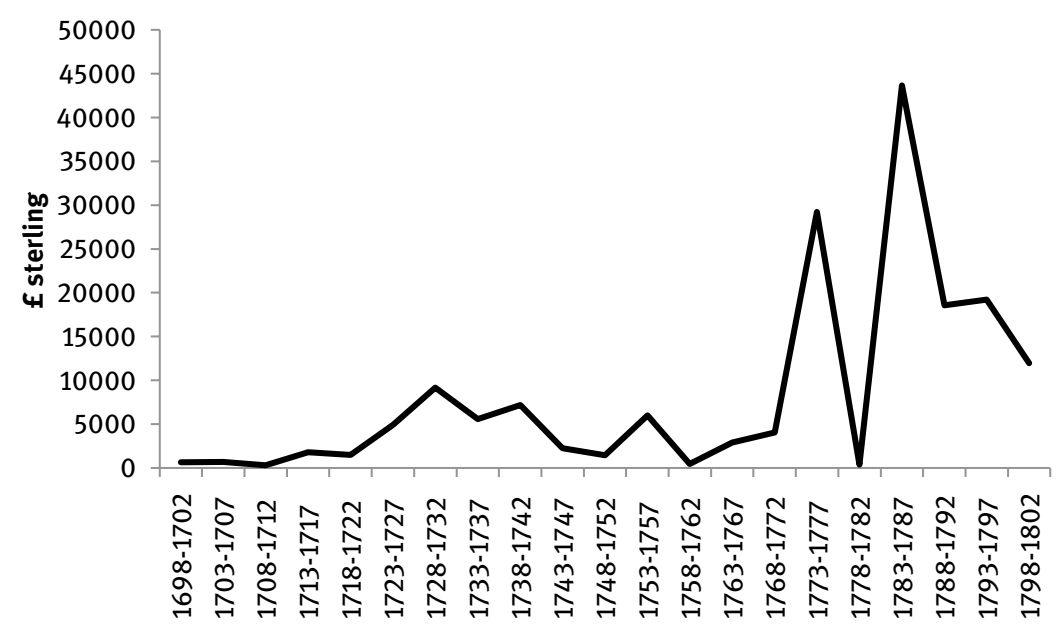

Figure 7: Value of British watches imported to the Ottoman Empire, 1698-1802..$^{64}$

Of course, a number of factors can account for the growing popularity of British watches, not least changing patterns of consumption within the Ottoman court and wider Ottoman elite society, and the increasing use of watches by state officials towards the century's end. Nonetheless, there is a significant correlation between the increase in watches given from the late 1710s and the significant increase in imported watches in the same period, indicating that the gifts of watches given to Ottoman officials had at least some role in generating interest among Ottoman officials across the century for British timepieces. The attention paid to fashioning timepieces that were of an appropriate aesthetic for social and ceremonial gift-giving meant that by the final decades of the eighteenth century, British clockmakers like Markwick Markham and George Prior had a tested and accepted set of designs and materials to work with, whilst the use of watches in official gift-giving, notably in the customhouse, pushed watches as a commodity of value.

64 TNA, CUST3/1-80. TNA, CUST17, 7-25. N. B. As the clerks of the customs records did not adjust for inflation in the eighteenth century, the pounds sterling here represent a constant value series. 


\section{Conclusions}

The story of clocks and watches in British-Ottoman diplomacy in the eighteenth century is one of a number of overlapping and interreferential facets that show a system of diplomatic practice in flux on a number of levels. In the account records, four different stories can be observed to play out by examining the details of the entries and narratives for these timepieces over 110 years. The first is the development of watches and clocks as social gifts to Ottoman officials to secure friendships, reward good services, and avoid disputes from the later seventeenth century, shifting from the 1730s towards a role in annual tributary gift-giving events and the rarer ceremonial accompanying a new ambassador's arrival. The second is the related shift in the nature of recipients of timepieces, from court favourites, secretarial officials, and provincial administrators up to the 1720 s, moving to the higher officers of state and the lower but equally crucial officials of the customhouse. Third, the material nature of the watches changes, from an almost equal mix of gold and silver watches up to the 1740s, with the gold watches almost entirely disappearing when the records resume in the 1760s. Finally, the trends in timepieces being gifted are in some respects mirrored in the commercial records of British watches imported to the Ottoman Empire, with a surge in interest between the 1720 s and 1740 s, and a dramatic increase in commercial success as watches became a staple import towards the century's end.

Establishing causal relationships between these different developments is not a particularly straightforward affair. Giving watches as social gifts meant giving them to a wider variety of officials, a large number of whom wanted or were given gold as well as silver watches, leading to a growing interest in watches as a commercial commodity. Similarly, a changing focus on diplomatic gifts saw watches being given to specific officials on specific occasions, notably on the renewal of the customs tariffs, with their commodification meaning that good quality silver watches largely sufficed, and the gifting of watches to customs officials helping to secure British trade and further market British watches, leading to an increase in British watches bought in the Ottoman market. However, there are a number of different elements beyond these simple assertions. Was there a change in aesthetic? We might trace the transition from watches embellished with engravings to those marked by painted cases. We might also use these watches to reflect on a shift from Ottoman power to British power. The changing power relations between Britain and the Ottoman Empire, with the former becoming more aggressive and less inclined to view the latter as an equal partner, and with the latter beginning to change its administrative system to a more centralised and bureaucratic sate than it had been earlier in the century. 
The clocks and watches examined here stopped ticking a long time ago. Most are probably lost forever as physical objects. Yet, in the accounts ledgers, they remain as functioning objects, and from this the various narratives of form, function, use, and destination become partially revealed. In his seminal study on 'The Social Life of Things', Arjun Appadurai proposed that "even though from a theoretical point of view human actors encode things with significance, from a methodological point of view it is the things-in-motion that illuminate their human and social context," and, more than this, that "all efforts at defining commodities are doomed to sterility unless they illuminate commodities in motion." ${ }^{65}$ In this paper I have attempted to show different forms of the motion of these timepieces, from their passage from the British embassy to a variety of Ottoman officials, to the shift from certain kinds of officials and occasions to others and differences in materials over time, to the movement back to the British for broken timepieces, and a broader movement of watches as commodities from Britain to the Ottoman realms. Some elements of these timepieces as things-in-motion are difficult, if not impossible to trace, particularly in being passed from one Ottoman official to another as part of their own gift-giving practices. Nonetheless, by combining financial records with material evidence and wider textual sources, the role of timepieces in British-Ottoman diplomacy in a variety of forms sheds light on otherwise unrecorded diplomatic practices, illustrates the intertwined nature of commercial interest and diplomatic practice, and thus emphasises the importance of objects as sources for the workings of historical diplomacy.

65 Arjun Appadurai: Introduction: Commodities and the politics of value, in: Arjun Appadurai (ed.): The Social Life of Things: Commodities in Cultural Perspective. Cambridge 1986, 3-63, here $5,16$. 